\title{
Study on the Universal Awareness of Participation in Social Governance and Its Influencing Factors
}

\author{
A Case Study of Zhongshan City
}

\author{
Tingying Li \\ School of Political Science and Public Administration, \\ University of Electronic Science and Technology of China \\ Chengdu, China
}

\begin{abstract}
Based on the spot check data of the public participation consciousness and behavior of Zhongshan city, extract the independent variables and the dependent variables via the method of principal component analysis, set up the regression model, and analyze the relation between the public participation consciousness and the various independent variables via regression model of OLS. The result display: there is a positive correlation between citizen participation consciousness and government executive power and citizen's sense of power and responsibility. On this basis, further analyze the influence caused by the variables such as the gender, age, education, monthly income, occupation to the civic participation consciousness.
\end{abstract}

Keywords-civic participation consciousness; government execution; civil rights and responsibilities; multiple regression analysis

\section{PROBLEM DESCRIPTION}

Public participation means in the process of social governance the citizen can fully exercise their right to speak, open their own opinions and reasons, and respect their opinions, and every citizen and their groups have equal opportunity to express their idea, so as to protect the interests of individual citizens and groups.

Since 2011, Zhongshan city, in Guangdong province, has insisted the idea of inclusive growth, share the duties and fruits', break the dual structure of urban and rural area and cities, integrate into the essence of participatory governance into social governance practices, take the social governance and public demand as guide, take it as the goal that to promote the social containment development and enhance the people's achievement sense of reform and development, deeply carry out more than 10 actions of social governance joined by public, such as public cultivation, public writing, public security, public pioneering work, public drug control and public welfare and so on, form a new pattern of social governance that all people join in, want to join in, can join in and actually join in, and finally form a good situation of social governance joined by public and achievements shared by public, too.

\author{
Xi Yang \\ School of Political Science and Public Administration, \\ University of Electronic Science and Technology of China \\ Chengdu, China
}

\section{RESEARCH PROCESS AND LITERATURE REVIEW}

\section{A. Research Process}

The idea of public participation consciousness originates from the consciousness of public participation, and comparatively speaking, the related literature about the consciousness of public participation is relatively large. Scholars in various research fields have summarized the related issues of citizen participation consciousness and the research trend of citizen participation consciousness. Citizen participation has been as the subject in various research fields, the relevant scholars and institutions have done the research in different degree on the impact of citizen participation in various fields, and also make the relevant research and discussion on how to improve the citizen participation consciousness. In fact, the citizen participation conscious not only reflects the social governance ability of the government, but also serves as a prerequisite for developing a serviceoriented government, ensuring the improvement of people's livelihood and achieving good governance in society.

It is shown in Fig. 1 that since 2002, the number of published papers has been increased, in 2008, it break the number of 100, and then the trend become steady upward after that, in 2014, the number achieved the top that 188 papers had been published, the published papers have been decreased after that but it is still kept about 100 articles. In 1998, the twenty-fourth international administrative science conference was held in Paris, France, the meeting focused on the issues of civic participation and citizen expectation in the government and administrative functions. In 2003, China established the administrative legislative hearing system, and China's Participatory administration has entered a new stage. Therefore, China's Participatory administration is affected to some extent by western countries, but it is also a kind of social demand of our country's administrative development. In 2003, the party's the third Plenary Session of the 16th CPC Central Committee clearly pointed out that the government functions should change from "all-round type" to "service type", the establishment of service-oriented government need to fully understand the voice of public opinion, and to provide better services to citizens according to the needs of citizens. Therefore, under this premise, it is necessary for citizens to 
improve their sense of participation, break through the shackles of traditional ideas and participate in social management for their own benefit.

From 2004 to 2007, the party's Sixteenth and Seventeenth Congress adopted a series of policies and decisions on building a service-oriented government, took the construction of service government as an important content, in the 17th Congress of the $\mathrm{CPC}$, we further defined the service oriented government as the reform goal of our administrative system; The construction of service-oriented government can not be separated from the active participation of citizens, Therefore, during this period, the number of documents concerning the construction of citizen participation in service-oriented government is increasing. In 2013, the eighteenth party report put forward the idea of speeding up the reform of the social management system, and for the first time, the concept of social governance was adopted in the Third Plenary Session of the eighteen central committee; In the fifth Plenary Session of the 18th CPC Central Committee, we stressed the need to speed up innovation in social governance, promote the refinement of social governance, and build a social governance structure built and shared by all people. A series of new concepts that "all people", "share duties", "share fruits" have been put forward means that the social governance structure should insist on people foremost, and integrate the government governance, social coordination and public participation to provide a theoretical basis for the future reform in the social governance field of our country, therefore, in 2014, there was a "blowout" of 188 papers on the consciousness of citizen participation. After that, although it dropped somewhat, it remained at the level of about one hundred articles.

The above analysis shows that the development of consciousness of citizen participation in China has been affected by Western countries, but it is also the inevitable trend of social governance reform and innovation in China, which meets the needs of social governance development. At the same time, influenced by the direction of the national policy, the time of the surge of the volume of publication has a high degree of agreement with the affirmation of the national leaders and the period of the introduction of the national policy "Fig. 1".

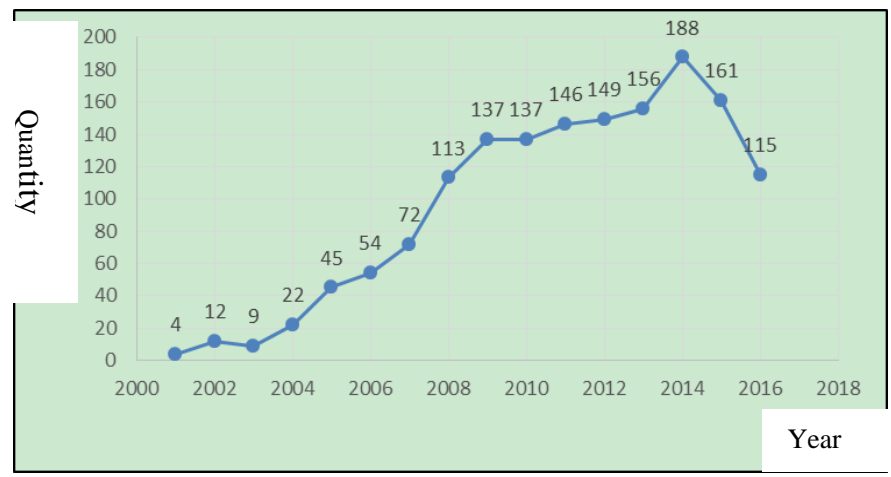

Fig. 1. The distribution of research literature on the citizen participation consciousness.
"Fig. 2" is a knowledge map CiteSpace III developed by Dr. Chen Chaomei of the University of Drake in the United States, the frontier time zone view of civic participation awareness is drawn from 1520 core journal articles. As can be seen from the figure, in the past 16 years, the focus of research on China's civic participation consciousness includes 30 kinds of mutant words: citizen participation, public policy and deliberative democracy and so on. The node with deeper color in the picture is the mutant word; these mutations have nothing to do with the frequency of use of keywords, but are detected by a sudden increase in the frequency of use of the keyword in the literature in a particular year. Combined with the discovery of mutant words, there are three tracks in the study of citizen participation consciousness in China: first, the focus of citizen participation is shifted from the formulation of public policy to the construction of government serviceoriented government; second, the field of citizen participation has shifted from political sphere to environmental protection field; third, citizen participation extends from political governance to social governance. These three tracks show the content development and hotspot transfer of citizen participation consciousness in China, which is closely related to the State concerning policy orientation of citizen participation consciousness, at the same time, it is closely related to social hot spots, such as environmental protection "Fig. 2".

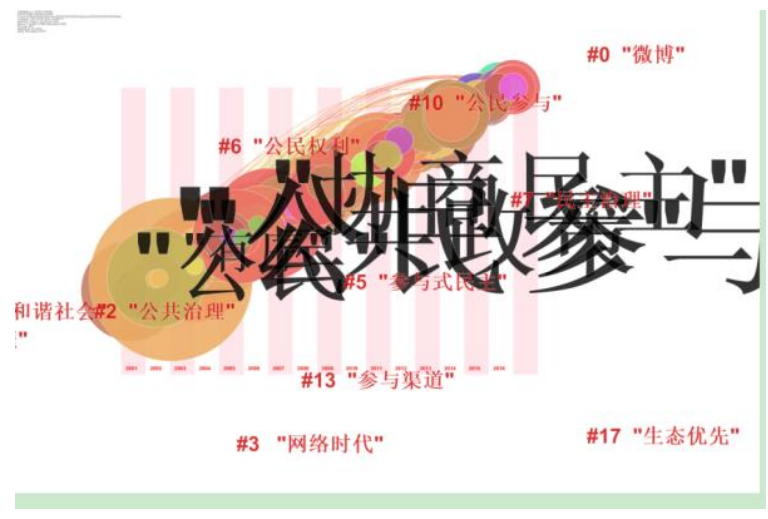

Fig. 2. Frontier time zone view of citizen participation consciousness.

Through the analysis of the time zone distribution of citizen participation consciousness and the frontier time zone view of citizen participation consciousness, we can see that there are more and more researches on the citizen participation in our country, and the theoretical knowledge is more and more substantial, and the cognition of citizen participation consciousness is more and more deep. Secondly, citizen participation is not confined to the formulation of public policy, but extends to all aspects of social governance, a wide range of civic participation can fully reflect the good development of democratic society, and also shows that the relationship between citizens and government is right and obligation, rather than the relationship of the citizen and the host

\section{B. Literature Review}

From angle of the citizen's participation in government performance, Guo Qingsong thinks that as the main service 
object of the government, it is reasonable that the citizen participates in the government performance evaluation and exercises the political rights.[1]

Sherry R. Arnstein, a western scholar, puts forward the ladder theory of citizen participation according to the degree of citizen participation", it includes non participation form, symbolic participation form and complete participation form [2], and however, our citizens' participation in social governance is still at the basic stage, that is what has mentioned by scholar Zhou Zhiren - "limited participation stage"[3]. However, in order to realize the target that make the deliberative democracy come true, build a service-oriented government and final achieve the public participation, it is necessary to break the situation that the Chinese citizens' participation in social governance is still in the basic stage, and to expand the breadth and depth of citizen participation.

The participation of citizens is directly related to the political environment of their country or region, especially the political system of the country and the democratic spirit of the political authorities. The citizen participation must have the corresponding political system safeguard and the political tolerant spirit; otherwise it is difficult to realize the real citizen participation. The political system of the country provides lawful channels, ways and places for citizens' participation, and when citizens' participation is infringed illegally, citizens' right to participate should be protected."[4] In current political environment, civic participation in social governance requires the democratic consciousness of citizens and the overall reform of the administrative system, rather than formalism.

From the point of interests, Zhang Yunlong explained that the government's perfect system guarantee is the influence factor of citizen participation consciousness, he believes that the fundamental cause of the "citizen participation is for the maintenance and realization of their own interests, no one is more concerned about their own interests than the citizen themselves, the problem is lies in that whether the way of interests realization can get the system guarantee or not, which is needed to be provided by the government and is also the basic function of the government." Perfect the existing political system, smooth the channels of effective participation, and guide the orderly participation of citizens, so as to avoid the outbreak of mass incidents.[5] The scholar, Bao Guoxian, when he analyze the impact of dynamic factors of citizen participation in government performance evaluation, he shows the government performance will impact the enthusiasm of citizens to participate the social governance from the several aspects of the institutional and legal guarantee, the level of economic development, civil society and the interests of the driving mechanism, the government departments should improve their own ability, and take serve the citizens as their purpose of work, the enthusiasm of participating in social governance activities will be improved accordingly, which will also improve the effectiveness of citizen participation in social governance.

From the scientific outlook on development of the implementation of public policy, Dr.Chen Dehui thinks that the citizen participation is the value orientation of public policy, and also is the inner demands of scientific outlook on development, the government mainly takes the citizenoriented service as its guide, and plays and serving, coordinating role in the public policy, and helps the citizen to express and realize their common interests. Therefore, the government should take their role in social services, actively respond to the social needs of the public, make the information open and transparent, smooth the channels of communication with citizens, set up the service-orientated society, wake up the citizens' sense of participation, cultivate the citizen's joining ability and guarantee the citizen's right of participation.[6]

Scholars Chen Yongsen believes that the reasons for the weak sense of modern citizen participation is mainly that China's democratic environment is not enough, the idea of Enlightenment has become superficial, not popularized, and China has no stable political system to cultivate the consciousness of civic participation. [7] This view coincides with the idea of Liang Jiyi, a scholar, who believes that the reason for the current lack of civic awareness is because the consciousness of subjects and the official standard seriously inhibited the social public space and the main status of citizens, and lead to the atrophy of the independent personality of citizens.[8]This view also reflects the current awareness of civic participation, the urgent need for improvement of the political environment, the government and related departments should gradually realize the transformation of government functions in order to improve citizens' awareness of participation and realize social participation and social governance, change from closed, autocratic and managing state gradually to open, democratic and serving status.

\section{VARIABLE SETting AND DATA DESCRIPTION}

\section{A. Variable Setting}

Citizen participation consciousness is the dependent variable of this article. This article is based on the survey data of the citizen of Zhongshan city carried out by the research group of 'citizen participation consciousness research of the public participation of Zhongshan city, Guangdong province', there are 5 items in the questionnaire designed for measuring the citizen participation consciousness, this article adopts the principal component analysis and take the extraction factors of the 5 items as its dependent variable, in order to instead the original depend variable with fewer independent variables under the conditions of without loss of original information, so that it is more robust measure the impact of the independent variable to the citizen participation behavior "Table 1".

TABLE I. LOAD MATRIX OF DEPENDENT VARIABLE FACTOR

\begin{tabular}{ll}
\hline \multicolumn{1}{c}{ Item } & \multicolumn{1}{c}{ Factor } \\
\hline 17 & 0.6864 \\
18 & 0.7447 \\
19 & 0.7461 \\
20 & 0.7194 \\
23 & 0.5878 \\
Variance contribution rate & 48.91 \\
Cumulative variance contribution rate & 48.91 \\
\hline
\end{tabular}

As shown in "Table I", the common degree of each item is more than 0.5 , to extract a factor by principal component analysis as the independent variable to measure the citizen 
consciousness, thus it is directly named as "citizen participation consciousness".

During the questionnaire process, there are 10items refer to the influencing factors to the participation consciousness of the people, and make the principal component analysis to the 10 items, remove the items don't meet the analyzing requirements, and there are 8 items referring to the participation factors, and then analyze them and there are 2 factors are extracted as the independent variables of this article "Table II".

TABLE II. LOAD MATRIX OF INDEPENDENT VARIABLE FACTOR

\begin{tabular}{|c|c|c|c|}
\hline Item & Factor 1 & Factor 2 & $\begin{array}{l}\text { Common } \\
\text { degree }\end{array}$ \\
\hline Participation way & 0.6748 & -0.0054 & 0.8224 \\
\hline $\begin{array}{l}\text { Transparent } \\
\text { government affairs }\end{array}$ & 0.5284 & -0.0679 & 0.8028 \\
\hline Security system & 0.7473 & 0.0644 & 0.7754 \\
\hline Publicity dynamics & 0.7687 & 0.0779 & 0.7494 \\
\hline $\begin{array}{l}\text { Satisfaction to the } \\
\text { government work }\end{array}$ & 0.7390 & -0.0630 & 0.7773 \\
\hline Traditional culture & -0.0380 & 0.7711 & 0.6259 \\
\hline Golden mean & 0.1178 & 0.8049 & 0.6134 \\
\hline Interpersonal trust & -0.0595 & 0.7147 & 0.6908 \\
\hline $\begin{array}{l}\text { Variance contribution } \\
\text { rate }\end{array}$ & 30.65 & 22.11 & \\
\hline Cumulative variance & 30.65 & 52.76 & \\
\hline
\end{tabular}

contribution rate

As shown in "Table II", the common degree of each item is more than 0.5 , according to the analysis result and the meaning of each item, the factor 1 is named as 'government execution ability', the factor 2 is named as 'the right and duty consciousness of citizens'. And the questionnaires included in the government execution ability are participation way, transparent government work, security system, publicity dynamics, satisfaction to government work; the questionnaires included in the right and duty of consciousness of citizens are traditional culture, golden mean, interpersonal trust. This article takes "whether pay attention to the news of Zhongshan city" as the controlling variables, and the answer 'Yes' $=1$, and 'No' $=0$.

In order to check the main factors affecting the citizen participation consciousness, this article controls the characteristic variables of the demography, such as gender, age, Hukou, education, political appearance, monthly income etc.. Among them, the gender is set as dummy variable in this essay, the male is assigned as ' 1 ', as the comparable team; the female is assigned as ' 0 ', as the baseline team. The age is divided into 1-5 age groups - 18-30 years old, 31-40 years old, 41-50 years old, 51-60 years old, 60 years old and above, and assigned five; and be assigned 1-5 in turn; the Hukou is set as dummy variable, the one belongs to Zhongshan city is set as ' 1 ', as the comparable team, and the other is set as ' 0 ', as the baseline team. The education level is divided into six stages, they are respectively junior middle school, senior high school or technical secondary school, college, undergraduate, master and doctor, and be assigned 1-6 in turn; Occupation is divided into officel state-owned enterprises $\backslash$ institutions, foreign enterprises, private enterpriseslfarmers, retiredlunemployed, and others, and be assigned 1-4 in turn; the average monthly income is divided into five grades, they are respectively below
2000RMB， 2000-4000RMB， 4001-6000RMB， 60018000RMB, 8000RMB and above, and be assigned 1-5 in turn "Table III".

TABLE III. INSTRUCTION OF VARIABLES

\begin{tabular}{|c|c|}
\hline Name of variables & Definition of variable \\
\hline Dependent variable & Citizen participation consciousness \\
\hline $\begin{array}{l}\text { Independent } \\
\text { variable }\end{array}$ & $\begin{array}{l}\text { Government execution ability; the right and } \\
\text { duty consciousness of the people }\end{array}$ \\
\hline Focus on news & $=1, \mathrm{Yes} ;=0, \mathrm{No}$ \\
\hline Sex & $=1$ Male $;=0$, Female \\
\hline Age & $\begin{array}{l}=1,18-30 \text { years old; }=2,31-40 \text { years old; } \\
=3,41-50 \text { years old }=4,51-60 \text { years old } ;=5, \\
60 \text { years old and above }\end{array}$ \\
\hline Hukou & $\begin{array}{l}=1 \text {, belongs to Zhongshan city ; }=2 \text {, don't } \\
\text { belong to Zhongshan }\end{array}$ \\
\hline Education degree & $\begin{array}{l}=1, \text { junior middle school and less than it; } \\
=2 \text {, senior high school or technical secondary } \\
\text { school } ;=3 \text {, college; }=4 \text {, bachelor } ;=5 \text {, } \\
\text { master; }=6 \text {, doctor }\end{array}$ \\
\hline Occupation & $\begin{array}{l}=1 \quad \text { officel state-owned enterprises } \\
\text { institutions ; }=2, \text { foreign enterprises, private } \\
\text { enterpriseslfarmers } \quad ; \quad=3 \\
\text { retiredlunemployed; }=4 \text {, others }\end{array}$ \\
\hline Monthly income & $\begin{array}{l}=1, \quad 2000 \mathrm{RMB} \& \text { below } ;=2,2000- \\
\text { 4000RMB; }=3,4001-6000 \mathrm{RMB} ;=4,6001- \\
\text { 8000RMB; }=5,8000 \mathrm{RMB} \text { and above }\end{array}$ \\
\hline
\end{tabular}

\section{B. Introduction of Data}

The survey objects of this time is the various townships residents in Zhongshan city, including Nanlang Town, Fusha Banfu, Tanzhou, Torch Development Zone, God bay, Triangle Town, Dongshen, Sanxiang, Xiaolan, Dayong, Shaxi, Henglan, Old town, Wugui mountain, Shiqi District, etc..Collect the data by means of standardized access, a total of 1117 questionnaires were issued and 1117 were recovered. After strict review, 1117 questionnaires were valid, the effective recovery rate is $100 \%$. Descriptive statistics of each variable are shown in "Table IV".

TABLE IV. DESCRIPTIVE STATISTICS

\begin{tabular}{|c|c|c|c|c|c|}
\hline Variables & $\mathbf{N}$ & Min. & Max. & Average & $\begin{array}{l}\text { Standard } \\
\text { deviation }\end{array}$ \\
\hline $\begin{array}{l}\text { Citizen } \\
\text { participation } \\
\text { consciousness }\end{array}$ & 1095 & -3.525 & 2.3797 & $-2.56 \mathrm{e}-0.9$ & 1 \\
\hline $\begin{array}{l}\text { Governmental } \\
\text { executive ability }\end{array}$ & 1085 & -3.8334 & 3.1407 & $4.17 \mathrm{e}-10$ & 1 \\
\hline $\begin{array}{l}\text { The right and } \\
\text { duty } \\
\text { consciousness } \\
\text { of citizen }\end{array}$ & 1085 & -2.4504 & 2.3743 & $6.46 \mathrm{e}-10$ & 1 \\
\hline sex & 1115 & 0 & 1 & 0.5040 & 0.5 \\
\hline age & 1114 & 1 & 5 & 1.7576 & 1.0751 \\
\hline Hukou & 499 & 0 & 1 & 1 & 0 \\
\hline $\begin{array}{l}\text { Education } \\
\text { degree }\end{array}$ & 1114 & 1 & 6 & 2.4820 & 1.1406 \\
\hline Occupation & 1106 & 1 & 5 & 2.5750 & 1.2301 \\
\hline Monthly income & 1090 & 1 & 5 & 2.2743 & 1.0896 \\
\hline Focus on news & 664 & 0 & 1 & 1 & 1 \\
\hline
\end{tabular}




\section{MODELING}

We set up the following measurement modeling in order to check the relationships among the citizen participation consciousness, governmental executive ability and the right and duty conscious of the citizens.

$$
\text { Participation }_{i}=\alpha+\beta \text { Government }+\gamma \text { Citizen }+\sum_{j=1}^{n} \delta_{j} X_{i j}+\varepsilon_{i}
$$

Among them, Participation $_{i}$ observe the citizen participation consciousness of ${ }^{i}$, Government is the independent variables - governmental executive ability,

\section{Citizen}

is the independent variables- the right and duty of the public. ${ }^{X_{i j}}$ is the controlled variable ${ }^{j}$ to observe ${ }^{i}$, including sex, age, educational degree, Hukou, occupation, monthly income etc., $\mathrm{n}$ is the number of controlled variables,

$\varepsilon_{i}$ is random variable.

The researching purpose of this article is to explore the relationship between the dependent variables and the independent variables, according to the angle of the citizen participation consciousness; the research hypothesis proposed by this research is like:

Hypothesis 1 : When the other conditions are not changed, the governmental executive ability is stronger; the citizen participation consciousness is higher.

Hypothesis 2: When the other conditions are not changed, the right and duty consciousness is higher, the citizen participation consciousness is higher.

In order to check the two research center, this research use stata12.0 software, adopt the OLS analysis method to evaluate the parameters, and take the governmental executive ability and the right and duty consciousness of citizen as the independent variable, and take the citizen participation consciousness as the dependent variable, and at the same time, and bring in the controlling variables such as the news focus of Zhongshan city and the individual features to do the regression analysis. And the result is shown in "Table V".

TABLE V. REGRESSION RESULT

\begin{tabular}{llll}
\hline \multicolumn{1}{c}{ Variables } & \multicolumn{1}{c}{ Coef. } & Std. Err. & P \\
\hline $\begin{array}{l}\text { Governmental executive } \\
\text { ability }\end{array}$ & 0.3274 & 0.02864 & 0.000 \\
The right and duty & 0.0558 & 0.0287 & 0.023 \\
consciousness of citizen & & & \\
Sex & 0.0465 & 0.0585 & 0.427 \\
Age & -0.0682 & 0.0288 & 0.018 \\
Career & -0.0471 & 0.0262 & 0.073 \\
Education degree & 0.0187 & 0.0270 & 0.488 \\
Monthly average income & 0.0736 & 0.0294 & 0.013 \\
Hukou & 0.0771 & 0.0592 & 0.193 \\
Focus on news & 0.3114 & 0.0598 & 0.000 \\
\hline Observation data & \multicolumn{3}{c}{1036} \\
\hline R2 & \multicolumn{3}{|}{0.17} \\
\hline
\end{tabular}

The regression results of table 5 show the coefficients of each control variable and their statistical significance, and the control variables were tested by significance test. The regression results show that both the governmental executive ability and the sense of power and responsibility of the citizens are positive, which shows that the executive ability of government and the sense of power and responsibility of citizens play a positive role in promoting citizen participation consciousness. That is to say, the governmental executive ability is stronger; the citizen participation consciousness is higher, hypothesis 1 is true; the right and duty consciousness of the citizens is higher, the citizen participation consciousness is higher, hypothesis 2 is true; the influence of gender on citizen participation consciousness is positive. In this paper, male is regarded as the comparable group; therefore, male citizens have a stronger sense of participation than female citizens. There is a negative correlation between age and citizen participation consciousness. The object of this questionnaire is $18-75$ years old, that is to say, with the increase of age, the consciousness of citizen participation in social governance activities is getting lower and lower. Occupation and citizen participation consciousness is negatively correlated, according to the assignment of the occupation variable, the regression results show that, the personnel in the office/ state-owned enterprises/institutions has the highest sense of civic participation, the citizen participation consciousness of the personnel in foreign enterprises, private enterprises/farmers is less than the mentioned group, the citizen participation awareness of the retired and unemployed and other occupation is the lowest. The results show that the nature of work and its professional level will influence citizen's sense of participation. Education level has a positive effect on citizen participation consciousness, and with the improvement of education level, citizens' awareness of participation in social governance is growing. The average monthly income and citizen participation consciousness is a positive correlation, and the regression results are significant, citizen participation awareness increases with the increase of the average monthly income, they will have excess energy to concern the social public affair only when their individual economy level is improved, and can meet their basic needs of life. The regression results show that the citizen has Hukou in Zhongshan city has higher participation sense than the one does not have Hukou of Zhongshan city, which shows that to settle in the local place will enhance the people's send of belonging, enhance the citizens' attention to the local public affairs.

The Zhongshan news is also from the side reflects the degree of concern of citizens in social affairs, is also a manifestation of people's sense of participation, therefore, the regression results also show that the news and citizen participation consciousness is a positive correlation, the more attention to the local news, the stronger consciousness of citizen participation.

\section{CONCLUSION}

The above empirical analysis shows that the consciousness of civic participation of Chinese citizens is constantly 
changing with the changing society. The government executive power and citizen participation consciousness promote each other and supplement each other, the citizen participation consciousness and the enthusiasm can be improved gradually only when the government provide a 'bottom-up' way for the people to reflect the content really wanted to be joined by citizens, and letting the invoice of the basic citizens can be responded, and setting up a 'responsive government'. The improvement of citizen participation consciousness will lead to active participation, and a series of related policies of the government will be made according to the public opinion at max. degree, and will be more legitimate in policy implementation. Therefore, in order to improve the citizen participation consciousness, it is necessary that to smooth channels for participation, improve the level of government affairs, improve the citizen participation in the security system, increase citizen participation in social governance propaganda, and strive to improve the citizens of the government's job satisfaction, and enhance citizens' trust in government. The consciousness of rights and responsibilities of citizens actually includes citizens' rights consciousness, sense of responsibility and legal consciousness, therefore, as long as citizens' rights, responsibilities and laws are improved, the citizens' consciousness of participating in social governance will be improved.

This study takes Zhongshan city as the research object to reflect the current social phenomenon, therefore, in the data collection may be restricted by geographical conditions, the influence factors of quantitative research on the consciousness of citizen participation is preliminary explored, it has not been able to provide a proper and objective theory to explain the results of the analysis, meanwhile, the measurement of each variable still needs to be improved, so the investigation and analysis of this time is only for reference, the problem of citizen participation consciousness needs further study.

\section{REFERENCES}

[1] Guo Qingsong. Government performance evaluation and the dynamic mechanism of citizen participation [J]. Journal of the Central Party school, 2009, 03:93-95.

[2] Sun Boying. Local governance in the age of Globalization: constructing the system platform of citizen participation and autonomous management $[\mathrm{J}]$. teaching and research, 2003, (11)

[3] Zhou Zhiren. Citizen participation in government performance evaluation: the practice course and prospect of China $[\mathrm{J}]$. Chinese administrative management, 2008, (1)

[4] Yu Keping. Several theoretical issues of civic participation [N]. learning times, 2006-12-18.

[5] Zhang Yunlong. Institutional guarantee of citizen participation consciousness, [J]. theory monthly magazine, 2006, 03:135-137.

[6] Cheng Dehui. Public participation: The logical necessity of Scientific Outlook on Development caused by public policy implementation of [J]. Journal of Zhengzhou University (PHILOSOPHY AND SOCIAL SCIENCES), 2012, 01:38-41.

[7] Chen Yongsen. An attempt to bid farewell to the subjects - Civic consciousness and civic behavior in the late Qing Dynasty and the early Republic of China.[M]. press of Renmin University of China,.2004, 1

[8] Liang Jiyi. Cultivation of civic awareness: The key to expand orderly political participation of citizens [J].

[9] Yu Minjiang, Liang Ying. An empirical analysis of the internal relationship between government trust and citizen participation consciousness - take Nanking as an example [J]. Chinese Administration management, 2008(08):121-125.

[10] Peng Daiyan, Yan Jing. The social trust and the life satisfaction - the survey based on the world outlook (WVS) The empirical analysis of some data of China[J]. Current economic research, 2004,(06):29-34. 